Acta Universitatis Lodziensis

www.czasopisma.uni.lodz.pl/foe/

$1(333) 2018$

DOI: http://dx.doi.org/10.18778/0208-6018.333.14

\title{
Tomasz Motowidlak
}

Uniwersytet Łódzki, Wydział Ekonomiczno-Socjologiczny,

Katedra Biznesu i Handlu Międzynarodowego, tmotowid@uni.lodz.pl

\section{Główne linie podziału między Komisją Europejską a Polską w zakresie polityki energetycznej}

Streszczenie: Ze względu na dominującą rolę węgla w strukturze wytwarzania energii oraz dużą zależność od importu gazu z Federacji Rosyjskiej, a także na upolitycznienie relacji gospodarczych z tym krajem, Polska jest narażona w sposób szczególny na niekorzystny wpływ niektórych działań i inicjatyw z zakresu polityki energetycznej, proponowanych przez Komisję Europejską. W artykule wykazano, że dotyczą one głównie rynku gazu i ochrony klimatu i obejmują w pierwszej kolejności dążenie do wzrostu dostaw rosyjskiego gazu do Unii Europejskiej oraz do ograniczenia emisji $\mathrm{CO}_{2}$ przez producentów energii. Przedstawiono wzajemne sprzężenia zachodzące między tymi działaniami i inicjatywami a gospodarczymi i politycznymi interesami Polski. Sformułowane wnioski obejmują możliwe negatywne skutki tych sprzężeń oraz propozycje ukierunkowania polityki energetycznej naszego kraju, które pozwolą na ograniczenie lub uniknięcie tych skutków.

Słowa kluczowe: polityka energetyczna UE, rynek gazu UE i Polski, system handlu emisjami UE, bezpieczeństwo energetyczne Polski

JEL: F52, O11 


\section{Wprowadzenie}

Inicjowana przez Komisję Europejską (KE) polityka energetyczna Unii Europejskiej (UE) jest realizowana zarówno w unijnym wymiarze geopolitycznym, jak i w wymiarze poszczególnych państw członkowskich UE. W pierwszym z tych wymiarów polityka ta zakłada osiągnięcie trzech zasadniczych celów, tj. liberalizację rynków energii i utrzymanie cen energii na możliwie niskim poziomie (cel R), ograniczenie negatywnego wpływu sektora wytwarzania energii na środowisko (cel E) i zapewnienie bezpieczeństwa dostaw energii (cel B). Wobec implementacji tych celów do prawodawstwa państw członkowskich UE, ich realizacja przebiega także w drugim z tych wymiarów. W ten sposób, w zamyśle KE, każde z państw członkowskich UE powinno przyczyniać się do ich osiągnięcia w unijnym wymiarze geopolitycznym.

Dotychczasowe efekty wdrażania polityki energetycznej wskazują, że proponowane przez KE kierunki wspólnych działań na rzecz osiągnięcia jej celów nie uwzględniają w wystarczającym stopniu interesów gospodarczych i politycznych niektórych państw członkowskich UE. Działania te pozwalają wprawdzie na częściową realizację celów tej polityki w unijnym wymiarze geopolitycznym (Motowidlak, 2010: 435), ale dzieje się to kosztem ich osiągania przez te państwa w wymiarze narodowym. Koszt ten ponoszą przede wszystkim te z nich, dla których istotnym nośnikiem energii jest węgiel, co trudno pogodzić z realizacją celu E. Z tego względu państwom tym niełatwo zaakceptować działania i inicjatywy proponowane przez KE, zmierzające do osiągnięcia tego celu, ponieważ wiążą się one z wysokimi nakładami inwestycyjnymi i ryzykiem wzrostu cen energii, a także z zagrożeniem dla bezpieczeństwa dostaw energii. W tych uwarunkowaniach ograniczona staje się zdolność tych państw do realizacji celów R i B.

Różne są reakcje państw członkowskich UE na działania i inicjatywy proponowane przez KE, ukierunkowane na wzrost dostaw gazu z Federacji Rosyjskiej (FR) oraz na ochronę klimatu. Zależą one w dużej części od relacji gospodarczych z FR i stopnia dywersyfikacji źródeł dostaw gazu na ich rynki oraz od roli węgla $\mathrm{w}$ zaspokajaniu ich potrzeb energetycznych. $Z$ rezerwą do działań $\mathrm{i}$ inicjatyw w zakresie rynku gazu, proponowanych przez KE, podchodzą te z państw, dla których oznaczają one ugruntowanie dominującej pozycji rosyjskiej spółki Gazprom na ich rynkach. Z kolei dla pozostałych państw członkowskich UE utrzymanie dobrych relacji gospodarczych z FR jest nierzadko wystarczającym powodem do stawiania swoich interesów narodowych ponad interesy państw dążących do zmniejszenia swojej zależności energetycznej od dostaw surowców z tego kraju. Działania i inicjatywy dotyczące ochrony klimatu, proponowane przez KE, bez entuzjazmu postrzegają te państwa członkowskie UE, dla których wykorzystanie węgla jest podstawą bezpieczeństwa energetycznego.

Podejmowanie działań i inicjatyw proponowanych przez KE, zmierzających do ochrony środowiska, to kierunek unijnej strategii, który Polska przyjęła i re- 
alizuje od początku transformacji polityczno-gospodarczej kosztem olbrzymich wyrzeczeń, zarówno ekonomicznych, jak i społecznych. Nasz kraj ograniczył bowiem w latach 2008-2012 o 28,9\% emisję $\mathrm{CO}_{2}$ (w stosunku do roku bazowego 1988), kilkakrotnie przekraczając sześcioprocentowy, wyznaczony protokołem z Kioto, poziom redukcji. Tymczasem kolejne działania i inicjatywy proponowane przez KE pomijają znaczenie węgla dla bilansu energetycznego Polski i zakładają obciążenie jej obowiązkiem dalszej redukcji emisji $\mathrm{CO}_{2}$ oraz rozwoju OZE.

Celem artykułu jest identyfikacja najtrudniejszych do wdrożenia dla Polski działań i inicjatyw w zakresie polityki energetycznej, proponowanych przez KE, oraz wskazanie ich efektów. Determinuje on hipotezę badawczą, zgodnie z którą efekty te niekorzystnie wpłyną na bieżącą i potencjalną pozycję gospodarczą i polityczną naszego kraju. Hipotezę tę zweryfikowano, posługując się analizą opisową oraz przyczynowo-skutkową. Pierwsza z tych analiz pozwoliła na określenie problematyki badań i rozpoznanie podstawowych zależności w jej obrębie, a druga na przypisanie efektów wspomnianym działaniom i inicjatywom, które proponuje KE.

\section{Niekorzystne dla Polski działania i inicjatywy dotyczące rynku gazu, proponowane przez KE}

W arsenale środków KE, służących poprawie konkurencyjności i bezpieczeństwa dostaw gazu do UE, dużą rolę odgrywają działania i inicjatywy zmierzające do zwiększenia dostaw surowca z FR (tab. 1). Narażają one Polskę na zwiększenie zależności od tych dostaw. KE dopuściła bowiem do uruchomienia w listopadzie 2011 roku pierwszej, a w październiku 2012 roku drugiej nitki gazociągu Nord Stream I (NS I), który umożliwił przesyłanie rosyjskiego surowca do Niemiec. Łączna jego zdolność przesyłowa wynosi $55 \mathrm{mld}^{3}$ gazu rocznie (Rosicki, Rosicki, 2012: 141). Z punktu widzenia zachodnioeuropejskich odbiorców rosyjskiego gazu wykorzystanie tego gazociągu może znacząco ograniczyć ryzyko wystąpienia zakłóceń w tranzycie surowca przez terytorium Ukrainy i Białorusi. Dodatkowo, wobec zdywersyfikowanej struktury źródeł dostaw, odbiorcy ci nie są narażeni na tak duże ryzyko ograniczenia lub wstrzymania dostaw rosyjskiego gazu jak państwa Europy Środkowo-Wschodniej (ESW), w tym Polska, i państwa Europy Centralno-Południowej.

Gazociąg NS I powstał bez konsultacji, między innymi z Polską, i wbrew argumentom ekonomicznym i ekologicznym, co może uzasadniać stwierdzenie, że jego budowa była inspirowana politycznie. Stąd też stwarza on ryzyko dla spójności UE oraz zagrożenie dla bezpieczeństwa energetycznego i ekonomicznego państw, które pomija. Dla Polski uruchomienie gazociągu NS I oznacza utratę sta- 
tusu istotnego państwa tranzytowego rosyjskiego gazu i możliwości kreowania polityki w regionie. Wykorzystanie tego gazociągu daje FR realną możliwość wywoływania kryzysów energetycznych w Polsce. Wywołać je można bowiem nie tylko w wyniku bezpośredniego ograniczenia lub wstrzymania dostaw gazu gazociągami Jamał i Braterstwo, bez narażania na straty kontrahentów niemieckich, ale także przez ograniczenie polskim odbiorcom możliwości korzystania z tzw. wirtualnego rewersu' ${ }^{1}$. Wobec przejęcia przez spółkę Gazprom kluczowych magazynów gazu w Niemczech i przepisów nakazujących ich priorytetowe zatłaczanie w przypadku kryzysu dostaw, ucierpieć może także rewers fizyczny, tj. możliwość przesyłania gazu z Niemiec do Polski.

Tabela 1. Niekorzystne dla Polski działania i inicjatywy w zakresie rynku gazu, proponowane przez KE

\begin{tabular}{|c|c|c|}
\hline $\begin{array}{l}\text { Motyw dzialań } \\
\text { i inicjatyw } \\
\text { proponowanych } \\
\text { nrzez KF }\end{array}$ & $\begin{array}{l}\text { Dzialania i inicjatywy } \\
\text { proponowane przez KE }\end{array}$ & Możliwe konsekwencje dla Polski \\
\hline \multirow{4}{*}{$\begin{array}{l}\text { Poprawa } \\
\text { konkurencyjności } \\
\text { i bezpieczeństwa } \\
\text { dostaw gazu }\end{array}$} & $\begin{array}{l}\text { Dopuszczenie do budowy gazociągu } \\
\text { Nord Stream I i wyłączenie } \\
\text { go spod przepisów III pakietu } \\
\text { energetycznego }\end{array}$ & \multirow{4}{*}{$\begin{array}{l}\text { - Ograniczenie roli Polski } \\
\text { jako państwa tranzytowego } \\
\text { i możliwości kreowania polityki } \\
\text { w regionie } \\
\text { - Duże ryzyko geopolityczne } \\
\text { wstrzymania lub ograniczenia } \\
\text { dostaw gazu z Rosji } \\
\text { - Spadek konkurencyjności } \\
\text { i bezpieczeństwa dostaw gazu } \\
\text { - Osłabienie koncepcji } \\
\text { dywersyfikacji źródeł dostaw } \\
\text { gazu } \\
\text { - Ograniczenie możliwości rozwoju } \\
\text { portu w Świnoujściu i Szczecinie }\end{array}$} \\
\hline & $\begin{array}{l}\text { Rozstrzygnięcia dotyczące } \\
\text { gazociągu OPAL }\end{array}$ & \\
\hline & $\begin{array}{l}\text { Brak jednoznacznie krytycznego } \\
\text { stanowiska wobec planów budowy } \\
\text { gazociągów Nord Stream II } \\
\text { i EUGAL }\end{array}$ & \\
\hline & $\begin{array}{l}\text { Niewystarczające wsparcie dla } \\
\text { gazowego projektu Bramy Północnej } \\
\text { i Korytarza Północ-Południe }\end{array}$ & \\
\hline
\end{tabular}

Źródło: opracowanie własne

Uruchomienie gazociągu NS I wzmocniło monopolistyczną pozycję spółki Gazprom na rynkach gazu państw ESW, w tym Polski, mimo że strategia KE zakłada dywersyfikację źródeł importu gazu. Pozwoliło ono tej spółce na podział regionalnych rynków gazu na mniejsze obszary i ich różnicowanie względem strategii dostaw, w tym polityki cenowej. Efekty te nie są spójne z dążeniami KE i UE do budowy jednolitego rynku gazu i energii. Sprzyjają one utrzymywaniu wobec Polski wyższych cen gazu od cen płaconych przez odbiorców zachodnioeuropej-

${ }^{1}$ Wirtualny rewers oznacza dla polskich przedsiębiorstw możliwość zakupu gazu od podmiotów z siedzibą na zachodzie Europy z fizycznym odbiorem surowca na terytorium Polski, tj. w punktach odbioru gazu na gazociągu jamalskim, zlokalizowanych we Włocławku i w Lwówku k. Poznania. 
skich oraz osłabiają pozycję naszego kraju w negocjacjach ze spółką Gazprom, dotyczących kolejnych kontraktów na dostawy gazu.

Wzmocnienie pozycji rynkowej spółki Gazprom na rynkach państw zachodnioeuropejskich oraz pozycji monopolistycznej na rynkach państw ESW było możliwe między innymi wskutek przyzwolenia KE na wyłączenie gazociągu NS I spod wymogów antymonopolowych dyrektywy 2009/93/UE, która jest jednym z zasadniczych dokumentów kształtujących politykę energetyczną $\mathrm{UE}^{2}$. W efekcie tego wyłączenia spółka Gazprom pozostaje jedynym dysponentem pełnej zdolności przesyłowej tego gazociągu, co wyklucza jej wykorzystanie przez konkurentów.

Przebieg gazociągu NS I może zablokować rozwój portów w Szczecinie i Świnoujściu. Porty te zgłosiły zastrzeżenia dotyczące głębokości jego ułożenia na odcinku, na którym krzyżuje się on z torem podejścia do portu w Świnoujściu. Polskie porty obawiają się, że głębokość 17,5 metra jest zbyt mała i uniemożliwi dostęp statkom o zanurzeniu powyżej 13,5 metra, w tym zbiornikowcom z gazem, które będą obsługiwać świnoujski terminal LNG.

$\mathrm{Na}$ mocy decyzji KE z dnia 28.10.2016 roku spółka Gazprom uzyskała od stycznia 2017 roku dostęp do $80 \%$, zamiast dotychczasowych $50 \%$, przepustowości gazociągu $\mathrm{OPAL}^{3}$, co pozwoli jej przesyłać od 7,7 $\mathrm{mld} \mathrm{m}^{3}$ do $10,2 \mathrm{mld} \mathrm{m}^{3}$ więcej gazu rocznie gazociągiem NS I przez Morze Bałtyckie (Yafimava, 2017). Decyzja ta nie tylko zagraża pozycji tranzytowej Polski i jej bezpieczeństwu dostaw gazu, ale podważa założenia UE dotyczące wspólnej polityki energetycznej. Nie tylko nie sprzyja konkurencji i dywersyfikacji źródeł gazu na rynki państw ESW, w tym Polski, ale ugruntowuje na tych rynkach dominację głównego dostawcy, tj. spółki Gazprom.

Należy zwrócić uwagę na to, że KE podjęła tę decyzję mimo uzyskania, w trakcie prowadzonego od 2012 roku śledztwa, potwierdzonych wniosków jednoznacznie wskazujących na wykorzystywanie przez spółkę Gazprom swojej monopolistycznej pozycji na rynkach gazu państw ESW, w tym Polski (Zaleski, 2017a). W ten sposób KE nie tylko uprzywilejowała spółkę Gazprom w kwestii dostępu do gazociągu OPAL, ale przyjęła propozycję ugody pozwalającej uniknąć kary finansowej, sięgającej 10\% jej rocznych przychodów, i zobowiązała rosyjskiego do-

${ }^{2}$ Dyrektywa 2009/93/UE dotycząca wspólnych zasad rynku wewnętrznego gazu ziemnego i uchylająca dyrektywę 2003/55/UE wchodzi w skład III pakietu energetycznego UE. Jej wymogi antymonopolowe przewidują m.in. stosowanie zasady dostępu stron trzecich do infrastruktury gazowej (Third Party Access, TPA) oraz zakaz łączenia działalności produkcyjnej i handlowej z działalnością w zakresie przesyłu i dystrybucji gazu (tzw. unbundling).

${ }^{3}$ Gazociąg OPAL (Ostsee Pipeline Anbindungs-Leitung) o przepustowości $36,5 \mathrm{mld} \mathrm{m}^{3}$ gazu rocznie został uruchomiony w lipcu 2011 roku. Stanowi on lądowe przedłużenie gazociągu Nord Stream I, które biegnie wzdłuż zachodniej granicy Polski w kierunku Czech. Na mocy decyzji KE z 2009 roku połowa tranzytowej przepustowości tego gazociągu została wyłączona spod antymonopolowych zapisów III pakietu energetycznego UE. 
stawcę gazu jedynie do ,podjęcia działań” zapewniających zgodną z unijnymi zasadami jego działalność w państwach ESW, w tym w Polsce (Basboga, 2016).

Polskie Górnictwo Naftowe i Gazownictwo SA (PGNiG SA) i rząd Polski są przekonane, że rozstrzygnięcie KE w sprawie gazociągu OPAL jest niezgodne z zapisami Traktatu o Unii Europejskiej, Traktatu o funkcjonowaniu Unii Europejskiej oraz Umowy Stowarzyszeniowej UE - Ukraina. Rozstrzygnięcie to zagraża bowiem konkurencji, dywersyfikacji źródeł i stabilności dostaw gazu nie tylko do Polski, ale do całej UE i dlatego nie spełnia ono warunków wyłączenia stosowania zasady TPA, które określono w artykule 36 ustęp 1 dyrektywy 2009/73/UE.

Za duży sukces PGNiG SA i polskiego rządu należy uznać postanowienie Trybunału Sprawiedliwości UE (TSUE) z dnia 23.12.2016 roku o zawieszeniu wykonania rozstrzygnięcia KE dotyczącego gazociągu OPAL. W podobnym tonie wypowiedział się sąd w Düsseldorfie, który 30.12.2016 roku wydał zakaz przeprowadzania aukcji na przepustowość tego gazociągu do momentu rozpatrzenia sprawy (Lohmann, 2017). Sukces ten jest tym cenniejszy, że polskie skargi na decyzję KE w sprawie gazociągu OPAL zostały złożone do obu wspomnianych instytucji zanim została ona oficjalnie opublikowana. Podkreśla on też istotę i trafność podnoszonej w tych skargach argumentacji, która, wobec zwłoki KE, dotyczącej komunikowania swojej decyzji zainteresowanym stronom, musiała zostać sformułowana niejako „w ciemno” (Maciążek, 2017a).

Istotną determinantą linii podziału między KE i Polską w zakresie bezpieczeństwa dostaw gazu jest projekt gazociągu Nord Stream II (NS II) ${ }^{4}$. W przypadku jego uruchomienia łączna przepustowość szlaków przesyłowych spółki Gazprom przez Morze Bałtyckie wyniesie $110 \mathrm{mld} \mathrm{m}^{3}$ gazu rocznie, co pozwoli jej na całkowite wyeliminowanie przesyłu surowca gazociągiem Braterstwo przez Ukrainę i Słowację oraz gazociągiem Jamał przez Białoruś i Polskę. Mimo to, dzięki wykorzystaniu gazociągów NS II i EUGAL oraz budowie interkonektorów gazowych, dostawy rosyjskiego gazu na rynki państw ESW, w tym Polski, mogą znacząco wzrosnąć. Mimo postępującej na świecie ekspansji gazu LNG wzrost tych dostaw może oznaczać „zacementowanie” gazem z FR „,na długo” rynków tych państw, w tym Polski (Maciążek, 2017b).

Funkcjonowanie gazociągów NS I i NS II oraz ich lądowych przedłużeń i zapewnienie im wyjątkowego traktowania w ramach unijnego III pakietu energetycznego może poważnie zaszkodzić realizacji projektu Bramy Północnej i podważyć

${ }^{4}$ Dążąc do zablokowania realizacji tego projektu, Polska była w marcu 2016 roku inicjatorką wspólnego listu państw ESW do KE, wskazującego na zagrożenie bezpieczeństwa energetycznego UE, które jest związane z tym projektem. W sierpniu 2016 roku Urząd Ochrony Konsumentów i Konkurencji podjął decyzję, która uniemożliwiła powołanie konsorcjum mającego finansować ten projekt. 
sens budowy interkonektorów gazowych w UE5. Realizacja tego projektu może bowiem zapewnić realną dywersyfikację źródeł dostaw gazu do Polski, a także do innych państw ESW. Dywersyfikacja ta zakłada bowiem uruchomienie rurociągowych dostaw gazu norweskiego w połączeniu z dostawami gazu LNG, realizowanymi za pośrednictwem obiektu w Świnoujściu.

Można sądzić, że projekt Bramy Północnej nie jest dostatecznie wspierany przez KE, która preferuje szersze wykorzystanie niemieckich gazociągów do przesyłania rosyjskiego gazu. Postawy KE nie zmienia zasadniczo fakt, że projekt ten ma stać się elementem Korytarza Gazowego Północ-Południe ${ }^{6}$, któremu sama przyznała w październiku 2013 roku status projektu o znaczeniu wspólnotowym (Project of Common Interest) (Regulation..., 2013). Warto, aby UE prowadziła efektywną politykę dywersyfikacji źródeł dostaw gazu i wspierała alternatywne projekty, takie jak Brama Północna, tj. polską propozycję dla państw ESW, która może być realnym narzędziem zmniejszania zależności UE od dostaw rosyjskiego surowca.

\section{Niekorzystne dla Polski działania i inicjatywy dotyczące ochrony klimatu, proponowane przez KE}

Ochrona klimatu, w wyniku dekarbonizacji źródeł energii, jest jednym z zasadniczych kierunków działań i inicjatyw w zakresie polityki energetycznej, proponowanych przez KE (tab. 2). Ten kontrowersyjny i kosztowny zarazem kierunek tej polityki jest szczególnie uciążliwy dla państw członkowskich UE, które do wytwarzania energii szeroko wykorzystują węgiel.

Wydaje się, że dla Polski skala negatywnego wpływu tych działań i inicjatyw może być proporcjonalna do różnicy, jaka istnieje między udziałem węgla w strukturze zużycia energii naszego kraju i UE. W 2014 roku w Polsce udział ten wynosił bowiem $53,2 \%$, podczas gdy w UE tylko $17,2 \%$. O dużej skali tego wpływu może także świadczyć $83,6 \%$ udziału węgla w strukturze wytwarzania energii elektrycznej w Polsce, który wyraźnie kontrastuje z 26,7\% udziału tego surowca w tej strukturze w UE (EU Energy in figures..., 2015).

Sztandarowym instrumentem polityki klimatycznej UE jest system handlu uprawnieniami do emisji $\mathrm{CO}_{2}$ (Emissions Trading System, UE ETS), stąd duża aktywność KE w jego reformowaniu. Inicjatywy KE dotyczące zmian funkcjo-

${ }^{5}$ Projekt Bramy Północnej obejmuje dwa zasadnicze elementy, tj. terminal LNG w Świnoujściu oraz tzw. Korytarz Norweski umożliwiający przesyłanie gazu ze złóż zlokalizowanych na Morzu Północnym. Docelowa przepustowość tego projektu wynosi $20 \mathrm{mld} \mathrm{m}^{3}$ gazu rocznie.

${ }^{6}$ Gazowy Korytarz Północ-Południe ma połączyć polski terminal LNG w Świnoujściu z chorwackim terminalem LNG zlokalizowanym na wyspie Krk. 
nowania tego systemu zmierzają do podniesienia cen tych uprawnień (European Union Allowances, EUA) w celu stymulowania rozwoju niskoemisyjnych technologii wytwarzania energii i produkcji przemysłowej (Motowidlak, 2016).

Tabela 2. Niekorzystne dla Polski działania i inicjatywy w zakresie ochrony klimatu proponowane przez KE

\begin{tabular}{|c|c|c|}
\hline $\begin{array}{l}\text { Motyw działań } \\
\text { i inicjatyw } \\
\text { proponowanych } \\
\text { nrzez KE }\end{array}$ & $\begin{array}{l}\text { Dzialania i inicjatywy } \\
\text { proponowane przez } \mathrm{KE}\end{array}$ & Możliwe konsekwencje dla Polski \\
\hline \multirow{4}{*}{$\begin{array}{l}\text { Ochrona klimatu } \\
\text { w wyniku dekar- } \\
\text { bonizacji źródeł } \\
\text { energii }\end{array}$} & $\begin{array}{l}\text { Działania na rzecz wzrostu cen } \\
\text { uprawnień do emisji } \mathrm{CO}_{2}\end{array}$ & \multirow{4}{*}{$\begin{array}{l}\text { - Spadek konkurencyjności węglo- } \\
\text { wych jednostek wytwórczych } \\
\text { - Wyłączenia węglowych jednostek } \\
\text { wytwórczych } \\
\text { - Brak ekonomicznych bodźców } \\
\text { do inwestycji w węglowe jednost- } \\
\text { ki wytwórcze } \\
\text { - Ograniczenie roli węgla w ener- } \\
\text { getyce } \\
\text { - Wzrost cen i spadek bezpieczeń- } \\
\text { stwa dostaw energii elektrycznej } \\
\text { - Odpływ środków finansowych } \\
\text { w związku z importem instala- } \\
\text { cji OZE }\end{array}$} \\
\hline & $\begin{array}{l}\text { Zaostrzanie wymogów w zakresie } \\
\text { emisji przemysłowych i emisji } \mathrm{CO}_{2}\end{array}$ & \\
\hline & $\begin{array}{l}\text { Działania na rzecz wyeliminowa- } \\
\text { nia elektrowni węglowych z rynku } \\
\text { mocy }\end{array}$ & \\
\hline & Preferencje dla rozwoju OZE & \\
\hline
\end{tabular}

Źródło: opracowanie własne

W lipcu 2012 roku KE zaproponowała wprowadzenie mechanizmu tzw. back-loadingu ${ }^{7}$, czyli czasowego wycofania 900 mln uprawnień EUA w latach 2014-2016, które miałyby powrócić na rynek w latach 2019-2020, gdy sytuacja się ustabilizuje (Healy, Gores, 2016). Ze stycznia 2015 roku pochodzi inicjatywa KE dotycząca mechanizmu rezerwy stabilizacyjnej (Market Stability Reserve, MSR) ${ }^{8}$, którego idea opiera się na wycofywaniu określonej liczby uprawnień EUA i przenoszeniu ich do specjalnej rezerwy w sytuacji, gdy ich liczba na rynku przekroczy $833 \mathrm{mln}$ (Levy-Abegnoli, 2015).

Oba mechanizmy pozwalają KE na interwencje na rynku uprawnień EUA i utrzymywanie ich cen na administracyjnie określonych (stosunkowo wysokich) poziomach i w konsekwencji wywieranie presji na energetykę węglową. Dla Polski

${ }^{7}$ Propozycja KE dotycząca mechanizmu back-loadingu została formalnie zatwierdzona rozporządzeniem KE 176/2016 z dnia 25.02.2014 r. „w celu określenia wolumenów uprawnień do emisji gazów cieplarnianych, które mają zostać sprzedane na aukcji w latach 2013-2020".

${ }^{8}$ Propozycja KE dotycząca mechanizmu MSR została formalnie zatwierdzona decyzją Parlamentu Europejskiego i Rady UE 2015/1814 z dnia 6.10.2015 r. w sprawie ustanowienia i funkcjonowania rezerwy stabilności rynkowej dla unijnego systemu handlu uprawnieniami do emisji gazów cieplarnianych i zmiany dyrektywy 2003/87/WE. Mechanizm MSR ma zacząć działać od 1.01.2019 roku. 
może to oznaczać konieczność stopniowej rezygnacji z tej energetyki i zastępowania jej energetyką gazową i odnawialną. W efekcie istnieje duże ryzyko uzależnienia polskiej energetyki od dostawców zewnętrznych i wystąpienia gwałtownych i niekorzystnych zmian w polskim górnictwie. Znacznie wzrosną ceny energii, co osłabi konkurencyjność przemysłu naszego kraju.

Nieprzewidywalność cen uprawnień EUA stwarza duże ryzyko dla przedsiębiorców inwestujących w energetykę węglową. Dodatkowo, wobec możliwości administracyjnego ograniczenia przez KE liczby uprawnień EUA na rynku, Polska najprawdopodobniej straci znaczną część dochodu, na który liczyła w wyniku sprzedaży tej ich części, którą uzyskała nieodpłatnie9.

Szczególnie restrykcyjne dla elektrowni węglowych są wymogi II pakietu klimatyczno-energetycznego UE przyjętego w październiku 2014 roku oraz dyrektywy 2010/75/UE (dyrektywy IED) dotyczącej ograniczenia emisji przemysłowych. W myśl zaproponowanego przez KE w styczniu 2014 roku projektu tego pakietu do $40 \%$ wzrósł limit redukcji emisji $\mathrm{CO}_{2}$ oraz do $27 \%$ udział OZE w bilansie energetycznym UE w perspektywie do 2030 roku $^{10}$. Efektem wejścia w życie z dniem 1.01.2016 roku zaproponowanej przez KE dyrektywy będzie konieczność wyłączenia z polskiego systemu elektroenergetycznego do 2023 roku prawie $5 \mathrm{GW}$ mocy. Węglowe jednostki wytwórcze, które nie będą mogły zostać dostosowane do wymogów dyrektywy IED, otrzymały zgodę na pracę w wymiarze co najwyżej 17500 godzin w okresie 2016-2023, tj. około 6 godzin dziennie.

Istotnym elementem dyrektywy IED, pozostającym w gestii KE i mającym charakter normy prawnej, są tzw. konkluzje BAT, które zapewniają KE możliwość określania, w drodze decyzji, najbardziej efektywnych technik prowadzenia danej działalności (Suhr, Klein, 2015). Dla polskiej energetyki konkluzje BAT oznaczają konieczność podjęcia kolejnych modernizacji, w celu spełnienia do 2021 roku jeszcze bardziej zaostrzonych wymogów dotyczących emisji związków siarki, azotu i pyłów.

Jeszcze bardziej problematyczna i mniej przyjazna dla polskiego sektora energetycznego jest inicjatywa KE zmierzająca do ujednolicania mechanizmów wsparcia konwencjonalnego wytwarzania energii elektrycznej w państwach członkowskich UE, wyrażona w pakiecie na rzecz czystej energii dla wszystkich Europejczyków (Clean energy for all Europeans legislative proposals, CLEN) opublikowanym w listopadzie 2016 roku. Propozycja wprowadzenia kryterium emisyjności $\mathrm{CO}_{2}$ na poziomie $550 \mathrm{~kg} / \mathrm{MWh}$ wyklucza bowiem w praktyce od 2025 roku wspar-

${ }^{9}$ Darmowy przydział uprawnień EUA był jednym z zasadniczych elementów kompromisu Polski i KE osiągniętego w 2008 roku podczas przyjmowania przez Parlament Europejski I pakietu klimatyczno-energetycznego.

${ }^{10}$ Pierwszy pakiet energetyczny z 2008 roku przewidywał m.in. dwudziestoprocentową redukcję emisji $\mathrm{CO}_{2}$ i dwudziestoprocentowy udział OZE w bilansie energetycznym UE w perspektywie do 2020 roku. 
cie nawet dla najbardziej nowoczesnych bloków węglowych, odpowiadających realizowanym aktualnie w Polsce, na przykład w Kozienicach, Opolu i Jaworznie, które będą emitowały $700 \mathrm{~kg} \mathrm{CO}$ w związku z wytworzeniem jednej megawatogodziny energii elektrycznej. W naszym kraju wsparcie to ma przyjąć formę rynku mocy i zakłada wynagradzanie konwencjonalnych wytwórców za utrzymywanie w stanie gotowości swoich mocy wytwórczych ${ }^{11}$. Na obecnym etapie rozwoju technologii przyjęcie tego kryterium jest równoznaczne z objęciem rynkiem mocy tylko jednostek gazowych lub wysokosprawnej kogeneracji i z wykluczeniem z niego elektrowni węglowych. Dla Polski oznacza to uciążliwe negocjacje zapisów tego pakietu, ponieważ w najbliższych latach elektrownie te będą gwarantem bezpieczeństwa dostaw energii elektrycznej w Polsce, chociaż udział węgla w wytwarzaniu tej energii zmniejszy się do 56,2\% w 2030 roku (Zaleski, 2017b).

Bez utrzymywania i budowy elektrowni węglowych i gazowych bezpieczeństwa energetycznego Polski nie mogą zapewnić OZE, preferencyjnie traktowane przez KE (Mielczarski, 2017). Poważną wadą OZE jest bowiem ich chimeryczny charakter, co wymaga zapewnienia ich rezerwowania przez te elektrownie, które, wobec niskich cen hurtowych energii elektrycznej oraz administracyjnego wsparcia OZE, stają się coraz mniej konkurencyjne. Zasada merit order ${ }^{12}$ oraz pierwszeństwo w dostępie do sieci dla OZE powodują, że okresy pracy elektrowni węglowych są coraz krótsze i ograniczają się do pracy szczytowej, tj. de facto usługowej wobec OZE (5 mitów polskiej elektroenergetyki, 2014). W efekcie elektrownie te nie są w stanie pokryć kosztów stałych swojej działalności, co eliminuje je z rynku.

W tych uwarunkowaniach aktywność KE na rzecz rozwoju OZE wkomponowuje się $\mathrm{w}$ proponowane przez nią działania i inicjatywy zmierzające do dekarbonizacji źródeł energii, która, jako jeden z zasadniczych kierunków polityki energetycznej UE, została wyraźnie wskazana przez KE w lutym 2015 roku w ramach pakietu regulacyjnego dotyczącego Unii Energetycznej (A Framework Strategy..., 2015). Kierunek ten jaskrawo kontrastuje z polskim postulatem wykorzystania rodzimych zasobów energii w UE ${ }^{13}$, sformułowanym w kwietniu 2014 roku przez Donalda Tuska. Realizacji polskiej koncepcji oparcia bezpieczeństwa dostaw energii elektrycznej na krajowych zasobach węgla nie sprzyja, zgłoszona przez KE w ramach pakietu CLEN, propozycja zapewnienia minimalnego udziału mocy transgranicznych w mechanizmach wsparcia OZE (Stanowisko Polskiego Komitetu Energii Elektrycznej..., 2016). Oznacza to, że niedobory energii elektrycznej w danym państwie członkowskim UE mają być w pierwszej kolejności pokrywa-

${ }^{11}$ Podstawowym zadaniem rynku mocy jest powstrzymanie spadku konkurencyjności tych wytwórców, który jest konsekwencją dynamicznego rozwoju OZE.

${ }^{12}$ Merit order jest sposobem rankingowania jednostek wytwórczych według kosztu zmiennego wytwarzania.

${ }^{13}$ Postulat ten był jednym z zasadniczych elementów projektu Unii Energetycznej. 
ne jej importem, a zwłaszcza importem energii odnawialnej. Propozycja ta oddala perspektywę utworzenia w Polsce rynku mocy, obliczonego na wsparcie konwencjonalnych jednostek wytwórczych, wykorzystujących rodzime zasoby węgla.

Niekorzystna dla Polski jest wysunięta przez KE w ramach pakietu CLEN propozycja zakładająca wykluczenie biomasy jako źródła OZE, o ile nie jest ona wykorzystywana w wysokosprawnej kogeneracji. W warunkach polskich biomasa jest bowiem istotnym instrumentem transformacji miksu paliwowego, stwarzającego możliwość wykorzystania zasobów lokalnych do wytwarzania energii elektrycznej (Stanowisko Krajowej Izby Gospodarczej..., 2017). Przyjęcie tej propozycji może oznaczać, że Polska nie osiągnie wyznaczonego jej na 2020 rok 15-procentowego udziału OZE w bilansie energetycznym i stanie się stałym płatnikiem na rzecz tzw. platformy finansowej ${ }^{14}$.

\section{Wnioski}

Wśród działań i inicjatyw proponowanych przez KE dla osiągnięcia celów polityki energetycznej UE najbardziej uciążliwe dla Polski, z punktu widzenia realizacji tych samych celów w wymiarze narodowym, są te z nich, które dotyczą rynku gazu oraz ochrony klimatu. Dla Polski nieuchronnym skutkiem ich wdrożenia będą bowiem następujące zasadnicze efekty w zakresie rynku gazu, które mogą niekorzystnie wpłynąć na jej bieżącą i potencjalną pozycję gospodarczą i polityczną:

1) wzmocnienie dominującej pozycji Gazpromu na tym rynku i w konsekwencji spadek konkurencji oraz wzrost ryzyka ograniczenia lub wstrzymania dostaw gazu, a także realizacji dostaw surowca o nieodpowiednich parametrach jakościowych;

2) deprecjacja dotychczasowych osiągnieć i planów Polski w zakresie dywersyfikacji źródeł i kierunków dostaw gazu;

3) ograniczenie roli przebiegającego przez Polskę gazociągu jamalskiego $\mathrm{i}-\mathrm{w}$ konsekwencji - możliwości kreowania przez nasz kraj polityki w regionie.

W celu ograniczenia tych efektów Polska powinna wzmocnić wysiłki zmierzające głównie do:

1) zablokowania lub znacznego opóźnienia budowy gazociągu NS II przez kwestionowanie jej zasadności i zgodności z zapisami Traktatu o UE, Traktatu o funkcjonowaniu UE, Umowy Stowarzyszeniowej UE-Ukraina oraz III pakietu energetycznego UE;

${ }^{14} \mathrm{~W}$ myśl pakietu CLEN platforma finansowa oznacza fundusz od 2021 roku zasilany wpłatami tych państw członkowskich UE, które nie osiągnęły wyznaczonego im przez KE udziału energii odnawialnej w swoich bilansach energetycznych. 
2) możliwie szybkiego wykonania planu bazowego, obejmującego realizację projektów Bramy Północnej i Korytarza Północ-Południe, które pozwolą na realną dywersyfikację kierunków i źródeł dostaw gazu;

3) rozbudowy terminalu LNG w Świnoujściu i uruchomienia pływającego terminalu LNG w Zatoce Gdańskiej w przypadku niepowodzenia planu bazowego.

Na bieżącą i potencjalną pozycję gospodarczą i polityczną Polski niekorzystnie mogą wpłynąć następujące efekty działań i inicjatyw proponowanych przez KE w zakresie ochrony klimatu:

1) osłabienie bezpieczeństwa energetycznego w wyniku ograniczenia roli rodzimych zasobów węgla w energetyce i zwiększenia zakresu wykorzystania importowanego gazu i niestabilnych OZE;

2) wzrost cen energii, będący konsekwencją wzrostu cen pozwoleń na emisje $\mathrm{CO}_{2}$ i spełnienia w energetyce wymogów klimatycznych UE, skutkujący spadkiem konkurencyjności gospodarki;

3) brak ekonomicznych bodźców do podejmowania inwestycji w energetyce węglowej i ograniczony dostęp do ich finansowania ze strony większości europejskich międzynarodowych instytucji finansowych.

Na ograniczenie tych efektów mogą pozwolić działania, wśród których można rekomendować przede wszystkim:

1) dążenie do uzyskania derogacji w zakresie spełnienia wymogów klimatycznych UE przez wskazywanie na surowcową specyfikę struktury wytwarzania energii i negatywne gospodarcze i społeczne konsekwencje szybkiej jej zmiany;

2) odwoływanie się do regulacji prawnych i instytucji UE, w tym do TSUE ${ }^{15}$, i podnoszenie kwestii możliwości swobodnego kształtowania miksu energetycznego przez państwa członkowskie UE w sposób gwarantujący bezpieczeństwo energetyczne oraz naruszania zasady pomocniczości;

3) rozwój ,czystych” technologii wykorzystania węgla, między innymi przez budowę sprawnych i niskoemisyjnych elektrowni węglowych;

4) stworzenie mechanizmu redukcji $\mathrm{CO}_{2}$, opartego na wykorzystaniu zasobów leśnych i zabieganie o jego uwzględnienie w systemie ETS.

Formułując powyższe wnioski, wynikające $\mathrm{z}$ realizacji celu artykułu i z pozytywnej weryfikacji hipotezy badawczej, należy wskazać na potrzebę prowadzenia dalszych badań nad lokalizacją linii podziału między KE a Polską w zakresie polityki energetycznej. Lokalizacja ta może bowiem ulec znaczącej zmianie między innymi w wyniku decyzji USA o wycofaniu się ze swoich zobowiązań podjętych w ramach światowego porozumienia o ograniczeniu emisji gazów cieplarnianych, będącego efektem konferencji COP 21, która odbyła się w Paryżu w grudniu 2015 roku, a także wystąpienia Wielkiej Brytanii z UE.

${ }^{15}$ Polska zaskarżyła w TSUE m.in. propozycje KE dotyczące przydziału limitów emisji $\mathrm{CO}_{2}$ na lata 2008-2012, mechanizmu rezerwy stabilizacyjnej i gazociągu OPAL. 


\section{Bibliografia}

5 mitów polskiej elektroenergetyki (2014), PwC, ING, Warszawa-Katowice.

A Framework strategy for resilient Energy Union with a forward-looking climate change policy (2015), COM (2015) 80 final, Brussels.

Basboga M. (2016), Gazprom to propose EU antitrust settlement, www.naturalgasworld.com [dostęp: 27.10.2016].

EU Energy in figures: Statistical pocketbook (2015), Office of the European Union, Luxembourg.

Healy S., Gores S. (2016), Trends and projections in the EU ETS in 2016. The EU Emissions Trading Systems in numbers. EEA Report, European Environment Agency, Luxembourg.

Levy-Abegnoli J. (2015), EU parliament approves market stability reserve for emissions trading, www.theparliamentmagazine.eu [dostęp: 13.07.2015].

Lohmann H. (2017), OPAL-OLG Düsseldorf setzt Vollzug des OPAL-Vergleichsvertrages aus, www. energate-messenger.de [dostęp: 2.01.2017].

Maciążek P. (2017a), Rok 2016 przypieczętowat niemiecko-rosyjski sojusz gazowy, www.energetyka24.com [dostęp: 2.01.2017].

Maciążek P. (2017b), Wojna o OPAL: Rosjanie gromadza wyroki Trybunału Sprawiedliwości UE, które zignorowała Polska, www.energetyka24.com [dostęp: 1.02.2017].

Mielczarski W. (2017), Zima w Niemczech. Kto dostarczy energię kiedy stana wiatraki?, www.cire.pl [dostęp: 11.02.2017].

Motowidlak T. (2010), Efekty wdrażania polityki energetycznej Unii Europejskiej w zakresie rynku energii elektrycznej, Wydawnictwo Uniwersytetu Łódzkiego, Łódź.

Motowidlak U. (2016), Znaczenie wykorzystania paliw alternatywnych $w$ transporcie samochodowym dla rozwoju gospodarki niskoemisyjnej Unii Europejskiej, Wydawnictwo Uniwersytetu Łódzkiego, Łódź.

Regulation on guidelines for trans-European energy infrastructure (2013), nr. 347/2013, Brussels.

Rosicki R., Rosicki G. (2012), Znaczenie gazociagu Nord Stream dla Polski, „Przegląd Bezpieczeństwa Wewnętrznego", nr 6, s. 139-156.

Stanowisko Krajowej Izby Gospodarczej wobec propozycji KE dot. tzw. pakietu zimowego (2017), KIG, Warszawa.

Stanowisko Polskiego Komitetu Energii Elektrycznej dot. pakietu na rzecz czystej energii dla wszystkich Europejczyków (2016), PKEE, Warszawa.

Suhr M., Klein G. (2015), Best available techniques (BAT). Reference document for the production of pulp, paper and board, European Commission, Luxembourg.

Yafimava K. (2017), The Opal exemption decision: Past, present and future, The Oxford Institute for Energy Studies, University of Oxford, Oxford.

Zaleski P. (2017a), Polska odpowiedź na OPAL: konieczna skarga do Trybunału Sprawiedliwości UE, www.energetyka24.com [dostęp: 7.01.2017].

Zaleski P. (2017b), Polska została ,ukarana” za efektywność realizacji polityki klimatycznej, www. energetyka24.com [dostęp: 3.01.2017]. 


\title{
The Main Dividing Lines Between the European Commission and the Polish in the Field of Energy Policy
}

\begin{abstract}
Due to the dominant role of coal in the structure of energy production and the high dependence on gas imports from the Russian Federation and together with politicization of economic relations with this country, Poland is particularly exposed to the unfavorable influence of some European Commission's policies and initiatives in regards to energy policy. The paper has shown that they mainly concern the gas market and climate protection and include, first of all, the drive to increase the supply of Russian gas to the European Union and to reduce $\mathrm{CO}_{2}$ emissions by energy producers. The reciprocal links between these policies and initiatives and the economic and political interests of Poland have been presented. The conclusions drawn from this paper may include the possible negative effects of these links and proposals how to direct our country's energy policy in order to limit or avoid these effects.
\end{abstract}

Keywords: EU energy policy, EU and Polish gas market, EU emissions trading system, energy security of Poland

JEL: F52, O11

\begin{tabular}{|l|l|}
\hline \multirow{2}{*}{ OPEN ACCESS } & $\begin{array}{l}\text { C by the author, licensee Łódź University - Łódź University Press, Łódź, Poland. } \\
\text { This article is an open access article distributed under the terms and conditions } \\
\text { of the Creative Commons Attribution license CC-BY } \\
\text { (http: //creativecommons.org/licenses/by/3.0/) }\end{array}$ \\
\cline { 2 - 2 } \\
Received: 2017-06-24; verified: 2017-12-13. Accepted: 2018-01-08
\end{tabular}

